\title{
Silage production of corn intercropped with tropical forages in an integrated crop-livestock system with lambs
}

\author{
Cristiano Magalhães Pariz(1), Ciniro Costa(1), Carlos Alexandre Costa Crusciol(2), Paulo Roberto de Lima Meirelles ${ }^{(1)}$, \\ André Michel de Castilhos ${ }^{(1)}$, Marcelo Andreotti( ${ }^{(3)}$, Nídia Raquel Costa ${ }^{(2)}$ and Jorge Martinelli Martello(2) \\ (1)Universidade Estadual Paulista (Unesp), Departamento de Melhoramento e Nutrição Animal, Caixa Postal 560, CEP 18618-681 Botucatu, SP,
Brazil. E-mail: cmpzoo@gmail.com, ciniro@fmvz.unesp.br, paulom@fmvz.unesp.br, michel@fmvz.unesp.br (2)Unesp, Faculdade de Ciências
Agronômicas, Departamento de Produção e Melhoramento Vegetal, Rua José Barbosa de Barros, no 1.780, CEP 18610-307 Botucatu, SP, Brazil.
E-mail: crusciol@fca.unesp.br, nidiarcosta@gmail.com, jorgemartinelli@hotmail.com (3)Unesp, Faculdade de Engenharia, Departamento de
Fitossanidade, Engenharia Rural e Solos, Avenida Brasil, no 56, Centro, CEP 15385-000 llha Solteira, SP, Brazil. E-mail: dreotti@agr.feis.unesp.br
}

Abstract - The objective of this work was to evaluate the effect of intercropping systems between corn and tropical forages, at different cutting heights, on silage production, light interception, land use efficiency, intercropping competition factors, and pasture production. In the 2010/2011 and 2011/2012 crop seasons, two cultivation modalities were evaluated in the summer/autumn - monocropped corn with residual regrowth of signal grass (Urochloa decumbens) from the soil seed bank and corn intercropped with palisade grass (U. brizantha 'Marandu') - , in a factorial arrangement with two cutting heights for silage production -0.20 and $0.45 \mathrm{~m}$. After corn silage harvest, the forages were grazed by lambs in a semi-feedlot system, in the winter/spring. Monocropped corn and $0.45-\mathrm{m}$ cutting height both reduced dry matter yield for silage. Corn intercropped with palisade grass improved land use efficiency from 13 to $31 \%$ compared with monocropped crop, with land equivalent ratio greater than 1 . Palisade grass showed higher light interception than signal grass over the intercrop period with corn and provided greater forage yield for lambs to graze during winter/spring. Corn intercropped with palisade grass, compared with monocropped corn, especially at the cutting height of $0.45 \mathrm{~m}$, is a viable option for improving silage and pasture production, as well as land use efficiency in the integrated crop-livestock system.

Index terms: Urochloa, Zea mays, cutting height, land equivalent ratio, light interception.

\section{Produção de silagem de milho consorciado com forrageiras tropicais em sistema de integração lavoura-pecuária com cordeiros}

Resumo - O objetivo deste trabalho foi avaliar o efeito de cultivos consorciados entre milho e forrageiras tropicais, em diferentes alturas de corte, sobre a produção de silagem, a interceptação luminosa, a eficiência de uso da terra, os fatores de competição do consórcio e a produção da pastagem. Foram avaliados, nas safras 2010/2011 e 2011/2012, duas modalidades de cultivo no verão/outono - monocultivo de milho com rebrota do banco de sementes de capim-braquiária (Urochloa decumbens) e milho consorciado com capim-marandu ( $U$. brizantha 'Marandu') -, em arranjo fatorial com duas alturas de corte para ensilagem - 0,20 e 0,45 m. Após a colheita do milho para ensilagem, as forragens foram pastejadas por cordeiros semi-confinados, no inverno/ primavera. O monocultivo do milho e a altura de corte a $0,45 \mathrm{~m}$ reduziram a produtividade de matéria seca para ensilagem. O milho consorciado com capim-marandu melhorou a eficiência de uso da terra de 13 para $31 \%$, comparado ao monocultivo do milho, com relação de equivalência de uso da terra maior que 1 . O capimmarandu apresentou maior interceptação luminosa que o capim-braquiária, ao longo do período de consórcio com o milho, e proporcionou maior produção de forragem para o pastejo pelos cordeiros durante o inverno/ primavera. O milho consorciado com capim-marandu, comparado ao monocultivo do milho, principalmente na altura de corte de $0,45 \mathrm{~m}$, é uma opção viável para aumentar a produção de silagem e pastagem, bem como a eficiência de uso da terra em sistema de integração lavoura-pecuária.

Termos para indexação: Urochloa, Zea mays, altura de corte, equivalência de uso da terra, interceptação luminosa.

\section{Introduction}

Currently, the integrated crop-livestock system (ICLS) with no-tillage (NT) is becoming a good alternative for farmers, since it can improve economical income and sustainability of agriculture production in tropical regions. Therefore, the ICLS is being promoted as the "new green revolution" in the tropics (Mateus et al., 2007).

Pesq. agropec. bras., Brasília, v.52, n.1, p.54-62, jan. 2017

DOI: 10.1590/S0100-204X2017000100007 
The major limitation of NT in areas with dry winters, such as the Brazilian Cerrado and African savannas, is the low plant biomass accumulation during the autumn/winter and winter/spring periods, due to unfavorable weather conditions, especially low water availability (Crusciol et al., 2012). However, the ICLS associated with NT in these locations can minimize this drawback (Kluthcouski \& Aidar, 2003).

For corn silage production, Wu \& Roth (2005), compiling the results of 11 studies, reported that the conventional cutting height at $0.17 \mathrm{~m}$ is usually considered low and that the cutting heights at 0.40 $0.50 \mathrm{~m}$ above ground level are considered high. Increasing cutting heights improves the agronomic and chemical characteristics of corn silage; however, this practice may be economically unfeasible when the quality of the final product is not computed. For this reason, Rezende et al. (2015) recommended that the maximum cutting height for corn should be at $0.50 \mathrm{~m}$. In intercropping systems with tropical perennial grasses, low cutting heights can result in an increased removal of tillers, compromising pasture formation for the winter/spring period (Portes et al., 2000). However, the operational constraints of forage harvesters that are either coupled to tractors or self-propelled hamper cutting heights above $0.40-0.50 \mathrm{~m}$.

This shows that, despite the advances of several researches on issues related to intercropping systems, it is still important to assess: the effects of different cropping systems on forage growth and pasture recovery after the harvest of the main crops; and on the land equivalent ratio (LER) (Mead \& Willey, 1980), the relative crowding coefficient (K) (Agegnehu et al., 2006) and aggressiveness (A) (Takim, 2012), which are indexes related to the competition between crops and intercrops.

The vast majority of current studies on grain crops, such as corn, sorghum, and soybean, intercropped with tropical forages in the ICLS conducted in the Brazilian Cerrado do not assess grazing by animals (Crusciol et al., 2011, 2012, 2014; Mateus et al., 2011; Pariz et al., 2011a, 2011b; Costa et al., 2012). Therefore, researches with this approach and specifically with sheep and lambs (Ovis aries) are still essential in this context, since animal grazing with high stocking rates and inadequate management can reduce straw yield, besides affecting soil quality and crop productivity (Carvalho et al., 2010).
The objective of this work was to evaluate the effect of the intercropping system between corn and tropical forages, at different cutting heights, on silage production, light interception, land use efficiency, intercropping competition factors, and pasture production.

\section{Materials and Methods}

The experiment was conducted in the municipality of Botucatu, in the state of São Paulo, Brazil ( $22^{\circ} 51^{\prime} 01^{\prime \prime} \mathrm{S}, 48^{\circ} 25^{\prime} 28^{\prime \prime} \mathrm{W}$, at $777 \mathrm{~m}$ above sea level), during two consecutive growing seasons: 2010-2011 and 2011-2012. Until October 2010, the area was in fallow, predominantly with signal grass [Urochloa decumbens (Stapf) R.D.Webster 'Basilisk' (Syn. Brachiaria decumbens)] and annual broadleaf weeds. The climate of the region, according to the Köppen, is Cwa, i.e., tropical with dry winters and hot and rainy summers. The long-term average annual maximum and minimum temperatures from 1956-2013 are 26.1 and $15.3^{\circ} \mathrm{C}$, respectively; the annual average mean temperature is $20.7^{\circ} \mathrm{C}$; and the annual average rainfall is $1,358.6 \mathrm{~mm}$ (Cepagri, 2013). Monthly rainfall and the maximum and minimum temperatures during the experimental period are shown in Table 1 .

The soil is classified as a Typic Haplorthox Latossolo Vermelho distroférrico (Santos et al., 2006) - with 630, 90, and $280 \mathrm{~g} \mathrm{~kg}^{-1}$ clay, silt, and sand, respectively. The chemical characteristics of the soil were determined according to Raij et al. (2001), and the results at the $0.00-0.20$-m depth were: $\mathrm{pH}\left(\mathrm{CaCl}_{2}\right)$ 4.7; $46.5 \mathrm{~g} \mathrm{dm}^{-3}$ soil organic matter; $8.2 \mathrm{~g} \mathrm{dm}^{-3} \mathrm{P}$ (resin); and 45.7, 0.8, 21.4, 11.2, and $79.1 \mathrm{mmol}_{\mathrm{c}} \mathrm{dm}^{-3} \mathrm{H}+\mathrm{Al}, \mathrm{K}^{+}$, $\mathrm{Ca}^{2+}, \mathrm{Mg}^{2+}$, and cation exchange capacity, respectively; and base saturation of $42.2 \%$.

A randomized complete block design was used, with six replicates. The treatments were arranged in a $2 \times 2$ factorial scheme, consisting of two cropping systems and two cutting heights for silage production. The cropping systems were: monocropped corn with residual regrowth of signal grass from the soil seed bank; and corn intercropped with palisade grass [Urochloa brizantha (A.Rich.) R.D.Webster 'Marandu' (Syn. Brachiaria brizantha)], sown simultaneously. The cutting heights for silage were: 0.20 and $0.45 \mathrm{~m}$ above soil surface. The experiment was repeated in the same location, in the 2010-2011 and 2011-2012 growing seasons. Each plot consisted of 20 corn rows, 
$25 \mathrm{~m}$ long and spaced $0.45 \mathrm{~m}$ apart. The monoculture with palisade grass had the same size and the same number of replicates as the other treatments; however, it was only used for the evaluation of intercropping competition factors.

On 10/22/2010, signal grass and annual broadleaf weeds were desiccated with $1.080 \mathrm{~g} \mathrm{ha}^{-1}$ acid-equivalent of glyphosate and $670 \mathrm{~g} \mathrm{ha}^{-1}$ a.i. of 2,4-D amine. On $10 / 26 / 2010$, the plants were cut using a plant residue crusher, leaving $8.5 \mathrm{Mg} \mathrm{ha}^{-1}$ of straw on the soil surface. On 11/3/2010, surface liming was performed with $2.5 \mathrm{Mg} \mathrm{ha}^{-1}$ dolomitic lime (28\% $\mathrm{CaO}$ and $\left.20 \% \mathrm{MgO}\right)$. On 11/4/2010, gypsum was applied to the surface using $1.5 \mathrm{Mg} \mathrm{ha}^{-1}$ of agricultural gypsum $\left(\mathrm{CaSO}_{4} \cdot 2 \mathrm{H}_{2} \mathrm{O}\right)$ with $17 \% \mathrm{Ca}$ and $14 \% \mathrm{~S}$, following the recommendation of Cantarella et al. (1997). On 12/7/2010, the regrowth of signal grass and of annual broadleaf weeds was desiccated with $1.440 \mathrm{~g} \mathrm{ha}^{-1}$ glyphosate and $670 \mathrm{~g} \mathrm{ha}^{-1}$ 2,4-D amine, leaving $1.5 \mathrm{Mg} \mathrm{ha}^{-1}$ straw dry matter on the soil surface. On 12/14/2011 and 12/4/2012, grasses were dried applying $1,440 \mathrm{~g} \mathrm{ha}^{-1}$ glyphosate, in order to produce straw.

The corn (Zea mays L.) simple hybrid 2B587 HX, with an early life cycle, was used in all treatments. It was sown on December 20, 2010-2011, and on December 21, 2011-2012, at a 3-cm depth, with a notillage drill, at a density of 80,000 seeds per hectare and row spacing of $0.45 \mathrm{~m}$. For all treatments and in both growing seasons, the basic fertilization in the sowing furrows consisted of $36 \mathrm{~kg} \mathrm{ha}^{-1} \mathrm{~N}$ as urea, $126 \mathrm{~kg} \mathrm{ha}^{-1}$ $\mathrm{P}_{2} \mathrm{O}_{5}$ as triple superphosphate, and $72 \mathrm{~kg} \mathrm{ha}^{-1} \mathrm{~K}_{2} \mathrm{O}$ as potassium chloride, as suggested by Cantarella et al. (1997).

In the intercropping treatments, palisade grass was sown at a seed density of $10.8 \mathrm{~kg} \mathrm{ha}^{-1}$ (pure live seed of $60 \%$ ). The forage seeds were mixed with corn fertilizer and sown simultaneously with the corn, at an 8-cm depth.

Corn seedling emergence occurred 6 and 16 days after sowing on 12/26/2010 and 1/6/2012 in the first and second growing seasons, respectively. These differences were due to the absence of rainfall after sowing, in the second growing season (Table 1). Grass seedlings emerged at 11 and 18 days after sowing on $12 / 31 / 2010$ and $1 / 8 / 2012$ in the first and second growing seasons, respectively. On 1/7/2011 and 1/25/2012, 8 and $16 \mathrm{~g} \mathrm{ha}^{-1}$ a.i. of nicosulfuron were applied in the first and second growing seasons, respectively, and $1,250 \mathrm{~g} \mathrm{ha}^{-1}$ a.i. of atrazine, in both seasons, in order to reduce the initial growth of the grass seedlings and to control the emergence of some annual broadleaf weeds. The higher dose of nicosulfuron in the second growing season was due to the higher initial growth of grass seedlings, caused by the excess of rainfall in the first 25 days of January 2012, which delayed herbicide application.

Topdressing mineral fertilization was done in between corn rows, over the soil surface without

Table 1. Values for rainfall, for maximum and minimum temperatures, and for photoperiod during the study period, as well as long-term averages from 1956 to 2013 in the municipality of Botucatu, in the state of São Paulo, Brazil.

\begin{tabular}{|c|c|c|c|c|c|c|c|c|c|c|c|c|}
\hline \multirow[t]{2}{*}{ Climate characteristics } & \multicolumn{12}{|c|}{ Month } \\
\hline & Dec. & Jan. & Feb. & Mar. & Apr. & May & June & July & Aug. & Sept. & Oct. & Nov. \\
\hline & \multicolumn{12}{|c|}{ First growing season (2010-2011) } \\
\hline Monthly rainfall (mm) & 243 & 712 & 188 & 164 & 127 & 17 & 50 & 7 & 25 & 0 & 360 & 103 \\
\hline Mean maximum temperature $\left({ }^{\circ} \mathrm{C}\right)$ & 28.6 & 29.6 & 29.8 & 25.8 & 26.8 & 23.5 & 21.9 & 24.6 & 26.4 & 28.2 & 26.7 & 27.7 \\
\hline Mean minimum temperature $\left({ }^{\circ} \mathrm{C}\right)$ & 18.3 & 19.6 & 19.6 & 18.3 & 15.9 & 12.9 & 10.9 & 12.2 & 14.3 & 13.4 & 16.7 & 15.7 \\
\hline \multirow[t]{2}{*}{ Photoperiod (hour per day) } & 13.3 & 13.2 & 12.7 & 12.1 & 11.5 & 10.9 & 10.7 & 10.8 & 11.2 & 11.9 & 12.5 & 13.1 \\
\hline & \multicolumn{12}{|c|}{ Second growing season (2011-2012) } \\
\hline Monthly rainfall $(\mathrm{mm})$ & 143 & 357 & 167 & 59 & 250 & 78 & 228 & 23 & 0 & 51 & 159 & 104 \\
\hline Mean maximum temperature $\left({ }^{\circ} \mathrm{C}\right)$ & 30.5 & 29.3 & 32.1 & 30.8 & 28.5 & 23.9 & 21.5 & 23.5 & 25.8 & 28.1 & 29.7 & 27.9 \\
\hline Mean minimum temperature $\left({ }^{\circ} \mathrm{C}\right)$ & 17.8 & 17.5 & 20.1 & 18.4 & 17.7 & 13.9 & 14.2 & 12.6 & 14.4 & 15.6 & 18.1 & 19.2 \\
\hline \multirow[t]{2}{*}{ Photoperiod (hour per day) } & 13.3 & 13.2 & 12.7 & 12.1 & 11.5 & 10.9 & 10.7 & 10.8 & 11.2 & 11.9 & 12.5 & 13.1 \\
\hline & \multicolumn{12}{|c|}{ Long-term average (50 years) } \\
\hline Monthly rainfall $(\mathrm{mm})$ & 185 & 224 & 203 & 141 & 67 & 76 & 56 & 38 & 39 & 71 & 127 & 133 \\
\hline Mean maximum temperature $\left({ }^{\circ} \mathrm{C}\right)$ & 27.2 & 28.1 & 28.0 & 28.0 & 27.0 & 24.0 & 23.0 & 23.0 & 25.0 & 26.2 & 26.7 & 27.2 \\
\hline Mean minimum temperature $\left({ }^{\circ} \mathrm{C}\right)$ & 16.4 & 17.1 & 17.4 & 19.0 & 17.0 & 15.0 & 13.0 & 13.0 & 14.0 & 12.4 & 14.2 & 15.1 \\
\hline Photoperiod (hour per day) & 13.3 & 13.2 & 12.7 & 12.1 & 11.5 & 10.9 & 10.7 & 10.8 & 11.2 & 11.9 & 12.5 & 13.1 \\
\hline
\end{tabular}


incorporation to the soil, with: $90 \mathrm{~kg} \mathrm{ha}^{-1} \mathrm{~N}$ as urea and $67 \mathrm{~kg} \mathrm{ha}^{-1} \mathrm{~K}_{2} \mathrm{O}$ as potassium chloride, in the first growing season; and $150 \mathrm{~kg} \mathrm{ha}^{-1} \mathrm{~N}$ and $90 \mathrm{~kg} \mathrm{ha}^{-1}$ $\mathrm{K}_{2} \mathrm{O}$ in the second growing season. Topdressing was performed when the corn plants had five expanded leaves (V5) (Cantarella et al., 1997). The higher amounts of $\mathrm{N}$ and $\mathrm{K}_{2} \mathrm{O}$ applied in topdressing in the second season were due to nutritional deficiencies observed in the corn leaves in the first growing season.

On 6/9/2011 and 6/1/2012, grasses were fertilized with $60 \mathrm{~kg} \mathrm{ha}^{-1} \mathrm{~N}$ as ammonium sulfate, following the recommendation of Borghi et al. (2014) for areas in the first years under NT.

Lambs were reared under continuous stocking and fixed stocking rates of 133 animals per hectare, in a semi-feedlot arrangement. The average initial live weights of the lambs in the first and second growing seasons were 21.79 and $22.71 \mathrm{~kg}$, respectively, with average final live weights of 32.35 and $36.37 \mathrm{~kg}$. The initial animal stocking rates on the pastures were 2.9 and $3.0 \mathrm{Mg} \mathrm{ha}^{-1}$ body weight, and the final animal stocking rates were 4.3 and $4.8 \mathrm{Mg} \mathrm{ha}^{-1}$. The lambs were left on the pasture throughout the day and, at night, they entered the cote, where they were supplemented with additional corn silage (from the same treatment) and with a concentrate. The experiment lasted 70 days in both growing seasons, which comprehended five 14-day periods.

The average lengths of the corn season from emergence to the milk-grain stage at 33-34\% moisture were of 107 days in the first season and 102 days in the second one. From April 12 to 14, 2011, and from April 17 to 18, 2012, when $1 / 4$ of the grains reached the milk stage, the crops were harvested with a mechanical silage forage harvester with 12 knives (model JF C-120, JF Máquinas Agrícolas, Itapira, SP, Brazil). Before harvest, however, the final plant population and the number of ears in the useful plots - the four central rows, excluding $1.0 \mathrm{~m}$ at the end of each one - were determined and extrapolated to plants and ears per hectare. Corn, signal grass, and palisade grass were all harvested in the respective heights of the treatments. A representative sample was taken from the harvested material and dried in forced-air circulation, at $65^{\circ} \mathrm{C}$ for 72 hours, in order to determine dry matter weight of the grains per ear (DWGE), forage dry matter yield (FDMY), and grain yield (GY), which were extrapolated to $\mathrm{Mg} \mathrm{ha}^{-1}$.
The LER was calculated according to Mead \& Willey (1980), as: LER $=\left(\mathrm{Y}_{1,2} / \mathrm{Y}_{1,1}\right)+\left(\mathrm{Y}_{2,1} / \mathrm{Y}_{2,2}\right)$. Aggressiveness (A) was determined as described by Agegnehu et al. (2006), using the equations: $A_{\text {corn }}=\left[Y_{1,2} /\left(Y_{1,1} \times Y_{1,2}\right)\right]-\left[Y_{2,1} /\left(Y_{2,2} \times Y_{2,1}\right)\right]$ and $A_{\text {forage }}=\left[\left(Y_{2,1} /\left(Y_{2,2} \times Y_{2,1}\right)\right]-\left[\left(Y_{1,2} /\left(Y_{1,1} \times Y_{1,2}\right)\right]\right.\right.$, in which $\mathrm{Y}$ is the aboveground biomass and the suffixes 1 and 2 represent crop 1 (corn) and crop 2 (palisade grass). Therefore, $Y_{1,2}$ is the aboveground biomass of corn when grown in mixture with palisade grass; $Y_{1,1}$ is the aboveground biomass of corn when grown in monoculture; $\mathrm{Y}_{2,1}$ is the aboveground biomass of palisade grass when grown in mixture with corn; and $\mathrm{Y}_{2,2}$ is the aboveground biomass of palisade grass when grown in monoculture (Biabani et al., 2008).

The relative crowding coefficient $(\mathrm{K})$ was calculated as in Agegnehu et al. (2006), through the equation: $\mathrm{K}_{1}=\left(\mathrm{Y}_{1,2} \times \mathrm{Z}_{2,1}\right) /\left[\left(\mathrm{Y}_{1,1}-\mathrm{Y}_{1,2}\right) \times \mathrm{Z}_{1,2}\right]$ or $\mathrm{K}_{2}=\left(\mathrm{Y}_{2,1} \times \mathrm{Z}_{1,2}\right)$ $/\left[\left(Y_{2,2}-Y_{2,1}\right) \times Z_{2,1}\right]$, in which $Y$ is the aboveground biomass; the suffixes represent the same as in LER; $Z_{1,2}$ is the sown proportion of corn; and $Z_{2,1}$ is the sown proportion of palisade grass. The plant density of each species at corn harvest was determined for this calculation.

Every other ten days after emergence, until the harvest for silage, light interception (LI) was measured with a photosynthetically active radiation meter (model AccuPar LP-80, Decagon Devices, Inc., Pullman, WA, USA), in 100 points in the plots. Light intensity was measured around midday, under clear skies, above the canopy of corn, grasses, and at the ground level. After harvest and before the onset of the pasture grazing period, LI was also measured above grasses and at ground level. The leaf area index (LAI) was obtained using the same equipment.

During the grazing period, samples were taken to determine forage dry matter yield of the pasture (FDMYP), using the following procedure: for each 14-day period, all grass leaves and stalks were manually cut at ground level $\left(1.0 \mathrm{~m}^{2}\right.$ per plot $)$ using mechanical rotary mowers, in three representative points. The collected material was dried by forced-air circulation, at $65^{\circ} \mathrm{C}$ for 72 hours. Forage dry matter was weighed, and data from each period were summed and extrapolated to $\mathrm{Mg} \mathrm{ha}^{-1}$.

All data were initially tested for normality with the Shapiro-Wilk test (Shapiro \& Wilk, 1965), using the Univariate procedure of the SAS software (SAS 
Institute Inc., Cary, NC, USA), and showed normal distribution. Data were then analyzed with the Proc Mixed procedure also of SAS, and the Satterthwaite approximation was used to determine the degrees of freedom for the test of fixed effects, in which the cropping systems and cutting heights were considered as the fixed effects, and the blocks, as the random effects. Growing seasons were considered as a repeated variable, whereas the block $\times$ cropping system $\times$ cutting height interaction, as the subject. The covariance structure used in the analyses was autoregressive, which provided the best fit according to Akaike's information criterion. Results were reported as least square means and separated by the probability of differences (PDIFF) option. Mean separations were performed using the LSD test, at 5\% probability. LI was analyzed by regression, using the Proc REG procedure also of SAS, and the best adjustments were chosen according to the coefficient of determination $\left(\mathrm{R}^{2}\right)$, at $5 \%$ probability. Standard errors were represented with bars, and means were determined with the Proc Means procedure of SAS.

\section{Results and Discussion}

Despite the differences in temperature and rainfall during the two growing seasons (Table 1), the weather conditions were appropriate for monocropped or intercropped corn development, according to Bergamaschi et al. (2004) and Araujo et al. (2011). In January 2011, the $367 \mathrm{~mm}$ of rainfall occurred in the second and third days, whereas, in January 2012, the $357 \mathrm{~mm}$ of rainfall were distributed throughout the month. Rainfall between the post-harvest of silage and the transfer of lambs to the pasture was $125.4 \mathrm{~mm}$ in the first growing season and $513.4 \mathrm{~mm}$ in the second one.

The plant population and, consequently, the number of ears per hectare were lower for corn intercropped with palisade grass, compared with monocropped corn cultivated over signal grass regrowth (Table 2). This can probably be attributed to the higher competition ability of that grass in intercropping systems with corn, in comparison with signal grass regrowth (Costa et al., 2012). Palisade grass shows longer leaves and greater tiller elongation in these systems, which may be explained by the low light levels (Bernardino \& Garcia, 2009). Sowing the seeds of this forage with the fertilizer, at a soil depth of $8 \mathrm{~cm}$, combined with the application of sub-doses of the herbicide nicosulfuron, was not enough to compromise its shade adaptability in relation to signal grass (Figure 1). Moreover, since no signal grass seeds were used, its emergence was slow, as it was dependent on the soil seed bank. The plant population and number of ears were greater in the second growing season, possibly due to a reduction in grass competition because of the higher nicosulfuron dose applied.

The cutting heights had no effect on LI by corn or grasses, because the evaluation was until to harvest for silage, up to 100 days after emergence (DAE) of corn. In the second season, palisade grass showed greater LI after 66 DAE of corn (Figure 1), when the corn plants started to dry and, therefore, palisade grass was able to obtain more light. The ideal temperature range for the development of palisade grass is between 30 and $35^{\circ} \mathrm{C}$, and, at temperatures between 10 and $15^{\circ} \mathrm{C}$, growth is virtually nil (Costa et al., 2005). In March/April, the mean maximum temperature was about $26^{\circ} \mathrm{C}$ in the first growing season and $30^{\circ} \mathrm{C}$ in the second one (Table

Table 2. Plant population (PP), number of ears per hectare (NE), dry grain weight per ear (DGWE), forage dry matter yield (FDMY), and dry grain yield (DGY) of monocropped corn (Zea mays) with residual regrowth of signal grass (Urochloa decumbens 'Basilisk') and of corn intercropped with palisade grass ( $U$. brizantha 'Marandu') at two cutting heights for silage, in the 2010-2011 and 2011-2012 growing seasons.

\begin{tabular}{lcccccc}
\hline Treatment ${ }^{(2)}$ & PP & NE & DGWE & $\begin{array}{c}\text { FDMY } \\
\text { corn+grass } \\
\end{array}$ & $\begin{array}{c}\text { FDMY } \\
\text { of grass }\end{array}$ & DGY \\
\hline Crop systems & & & & & & \\
$\quad$ MC corn & $75.0^{*}$ & $74.5^{*}$ & $76.4^{* *}$ & $13.1^{*}$ & $0.2^{* *}$ & $5.7^{* *}$ \\
Corn + PG & 69.2 & 68.5 & 100.1 & 14.3 & 1.0 & 6.9 \\
\hline Cutting heights & & & & & & \\
$0.20 \mathrm{~m}$ & 70.1 & 70.8 & 87.6 & $14.5^{*}$ & $0.8^{* *}$ & 6.2 \\
$0.45 \mathrm{~m}$ & 74.0 & 72.2 & 88.9 & 12.8 & 0.4 & 6.4 \\
\hline Growing season & & & & & & \\
2010-2011 & 70.4 & 70.7 & 91.0 & 13.7 & 0.6 & 6.2 \\
2011-2012 & 73.8 & 72.3 & 85.5 & 13.7 & 0.6 & 6.4 \\
\hline Mean & 72.1 & 71.5 & 88.3 & 13.7 & 0.6 & 6.3 \\
\hline
\end{tabular}

*and**Significant by the LSD test, at 5 and $1 \%$ probability, respectively. MC, monocropped; PG, palisade grass. 
1), which helps to explain the LI differences between the growing seasons.

Early corn hybrids have their use in intercropped systems favored, as they present high rates of dry matter accumulation in early developtment stages, with high LI capacity, which is unaffected by competition with palisade grass (Crusciol et al., 2013). Furthermore, tropical forage grasses exhibit slow growth until approximately 50 days (Portes et al., 2000). At the
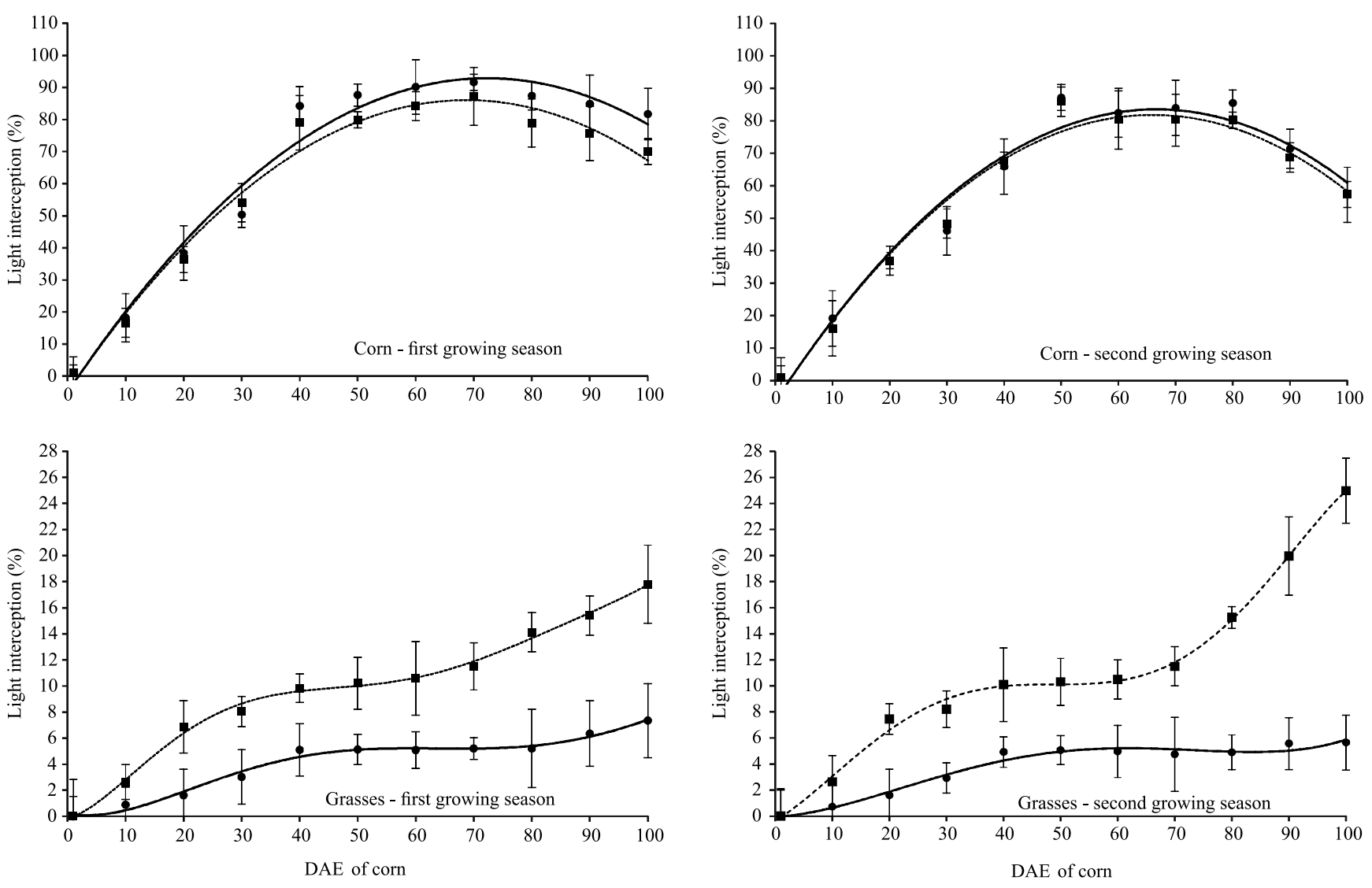

- Corn + signal grass regrowth (observed)

- Corn + palisade grass (observed)

-- Corn + palisade grass (estimated)

Figure 1. Light interception of corn monocropped with residual regrowth of signal grass (CSG) or corn intercropped with palisade grass (CPG) for silage as a function of the days after emergence (DAE), in two growing seasons. Values are the mean of 600 measurements (100 spots per six replicates), and bars represent the standard error. For the first growing season: light interception (\%) of corn in $\mathrm{CSG}=-5.0889+2.7100 \mathrm{DAE}-0.0187 \mathrm{DAE}^{2}\left(\mathrm{R}^{2}=0.974 ; \mathrm{p} \leq 0.01\right)$; and in $\mathrm{CPG}=$ $-4.9527+2.6485 \mathrm{DAE}-0.0193 \mathrm{DAE}^{2}\left(\mathrm{R}^{2}=0.982 ; \mathrm{p} \leq 0.01\right)$. Light interception $(\%)$ of grasses in $\mathrm{CSG}=0.2194-0.0843 \mathrm{DAE}$ $+0.0141 \mathrm{DAE}^{2}-0.0003 \mathrm{DAE}^{3}+3 \times 10^{-6} \mathrm{DAE}^{4}-1 \times 10^{-8} \mathrm{DAE}^{5}\left(\mathrm{R}^{2}=0.984 ; \mathrm{p} \leq 0.01\right)$; and in $\mathrm{CPG}=-0.1808+0.1356 \mathrm{DAE}+$ $0.0265 \mathrm{DAE}^{2}-0.0012 \mathrm{DAE}^{3}+2 \times 10^{-5} \mathrm{DAE}^{4}-2 \times 10^{-7} \mathrm{DAE}^{5}+5 \times 10^{-10} \mathrm{DAE}^{6}\left(\mathrm{R}^{2}=0.996 ; \mathrm{p} \leq 0.01\right)$. For the second growing season: light interception (\%) of corn in $\mathrm{CSG}=-6.4731+2.7011 \mathrm{DAE}-0.0203 \mathrm{DAE}^{2}\left(\mathrm{R}^{2}=0.967 ; \mathrm{p} \leq 0.01\right)$; and in $\mathrm{CPG}=-6.4161+$ 2.6759DAE - 0.0203DAE ${ }^{2}\left(\mathrm{R}^{2}=0.978 ; \mathrm{p} \leq 0.01\right)$. Light interception $(\%)$ of grasses in $\mathrm{CSG}=0.0582-0.0262 \mathrm{DAE}+0.0054 \mathrm{DAE}^{2}$ $-0.0001 \mathrm{DAE}^{3}+6 \times 10^{-7} \mathrm{DAE}^{4}\left(\mathrm{R}^{2}=0.973 ; \mathrm{p} \leq 0.01\right)$; and in $\mathrm{CPG}=-0.3465+0.2582 \mathrm{DAE}+0.0131 \mathrm{DAE}^{2}-0.0006 \mathrm{DAE}^{3}+6 \times 10^{-}$ ${ }^{6} \mathrm{DAE}^{4}-1 \times 10^{-8} \mathrm{DAE}^{5}-6 \times 10^{-11} \mathrm{DAE}^{6}\left(\mathrm{R}^{2}=0.997 ; \mathrm{p} \leq 0.01\right)$. 
of a subdose of nicosulfuron is required (Pariz et al., 2011a), as it was done in the present study.

The lower plant population and number of ears in the intercrop with palisade grass resulted in higher grain weights per ear, because of the reduced competition for water and nutrients in the grain-filling stage (Table 2). Therefore, despite the greater interspecific competition for light, the intercrop between corn and palisade grass (Figure 1) provided increased forage dry matter yield of corn + grass and higher grain yield in the fresh matter mass for silage. The higher dry matter yield of palisade grass also contributed to an increased dry matter mass for silage. The dry matter yield of corn + grass in the ensiled mass harvested at the cutting height of $0.45 \mathrm{~m}$ was lower than that at $0.20 \mathrm{~m}$.

The LER of corn intercropped with palisade grass was 16 and $3-4 \%$ higher than that of monocropped corn in the first and second seasons, respectively (Table 3), when the aboveground biomass of intercropped corn was lower. The LER of palisade grass intercropped with corn, however, was only $15 \%$ that of monocropped palisade grass in the first season and $9-12 \%$ in the second one. The corn, forage, and total LER values were similar at both cutting heights. The LER values for corn intercropped with palisade grass indicate that less area is required to produce the same amount of aboveground biomass, compared with the monocrop (Mateus et al., 2016).

In the first season, palisade grass exhibited weak interspecific competitiveness and corn a strong one, according to their $\mathrm{K}$ values (Mateus et al., 2016), which were extremely low for palisade grass and

Table 3. Land equivalent ratio (LER) for silage production, relative crowding coefficient (K), and aggressiveness (A) of corn (Zea mays) and palisade grass (Urochloa brizantha) intercropped, at two cutting heights, in two growing seasons ${ }^{(1)}$.

\begin{tabular}{|c|c|c|c|c|c|c|c|}
\hline \multirow{2}{*}{$\begin{array}{l}\text { Cutting } \\
\text { height }\end{array}$} & \multicolumn{3}{|c|}{ LER } & \multicolumn{2}{|c|}{$\mathrm{K}$} & \multicolumn{2}{|c|}{ A } \\
\hline & Corn & Forage & Total & Corn & Forage & Corn & Forage \\
\hline & \multicolumn{7}{|c|}{ First growing season (2010-2011) } \\
\hline $0.20 \mathrm{~m}$ & $1.16 \mathrm{a}$ & $0.15 \mathrm{a}$ & $1.31 \mathrm{a}$ & $-4.40 \mathrm{a}$ & $0.31 \mathrm{a}$ & $-0.0004868 \mathrm{a}$ & $0.0004868 \mathrm{a}$ \\
\hline \multirow[t]{2}{*}{$0.45 \mathrm{~m}$} & $1.16 \mathrm{a}$ & $0.15 \mathrm{a}$ & $1.31 \mathrm{a}$ & $-4.57 \mathrm{a}$ & $0.28 \mathrm{a}$ & $-0.0005010 \mathrm{a}$ & $0.0005010 \mathrm{a}$ \\
\hline & \multicolumn{7}{|c|}{ Second growing season (2011-2012) } \\
\hline $0.20 \mathrm{~m}$ & $1.04 \mathrm{a}$ & $0.09 \mathrm{a}$ & $1.13 \mathrm{a}$ & $11.07 \mathrm{~b}$ & $0.21 \mathrm{~b}$ & $-0.0001111 \mathrm{a}$ & $0.0001111 \mathrm{a}$ \\
\hline $0.45 \mathrm{~m}$ & $1.03 \mathrm{a}$ & $0.12 \mathrm{a}$ & $1.15 \mathrm{a}$ & $14.18 \mathrm{a}$ & $0.30 \mathrm{a}$ & $-0.0001917 \mathrm{a}$ & $0.0001917 \mathrm{a}$ \\
\hline
\end{tabular}

approximately zero for corn (Table 3 ). In the second season, both crops presented weak interspecific competitiveness, but corn showed, once more, greater competitiveness than palisade grass.

In both growing seasons, aggressiveness values were always negative for corn and always positive for palisade grass (Table 3), indicating that this perennial forage presented higher aggressiveness than corn. Corn showed high rates of dry matter accumulation (Figure 1), but its aggressiveness values were extremely low.

Harvest at the cutting height of $0.45 \mathrm{~m}$ resulted in less damage to the apical buds of palisade grass and in lower leaf removal. Consequently, a better recovery was observed, increasing LI and LAI after harvest and allowing pre-grazing by lambs in the winter/spring season (Tables 4 and 5). Due to its low height, signal grass regrowth was unaffected by cutting height. Palisade grass had greater LI and LAI than signal grass regrowth at both cutting heights. This was possible because the root system of the grass was better able to absorb water and nutrients at greater depths, promoting a better development than that of the old signal grass pasture (Pariz et al., 2011b).

The weather conditions, with greater rainfall (Table 1) and no frosts, after corn harvest for silage

Table 4. Light interception (LI), leaf area index (LAI), and forage dry matter yield of pasture (FDMYP) of signal grass (Urochloa decumbens) regrowth under corn (Zea mays) crop and of palisade grass (Urochloa brizantha) after intercropped with corn, at two cutting heights for silage production, in two growing seasons.

\begin{tabular}{|c|c|c|c|c|c|}
\hline \multirow[t]{2}{*}{ Treatment } & \multicolumn{2}{|c|}{$\begin{array}{l}\text { After harvest for } \\
\text { silage }\end{array}$} & \multicolumn{2}{|c|}{$\begin{array}{c}\text { Pre-grazing by } \\
\text { lambs }\end{array}$} & \multirow{2}{*}{$\begin{array}{l}\text { FDMYP } \\
\left(\mathrm{Mg} \mathrm{ha}^{-1}\right)\end{array}$} \\
\hline & LI (\%) & LAI & LI (\%) & LAI & \\
\hline \multicolumn{6}{|l|}{ Pastures } \\
\hline SG regrowth & $28.0 * *$ & $0.6^{* *}$ & $29.8 * *$ & $0.7^{* *}$ & $5.2 * *$ \\
\hline Palisade grass & 65.3 & 1.4 & 76.8 & 2.2 & 7.6 \\
\hline \multicolumn{6}{|l|}{ Cutting heights } \\
\hline $0.20 \mathrm{~m}$ & $43.5^{* *}$ & $0.9 *$ & $47.9 * *$ & $1.1 * *$ & $5.5^{* *}$ \\
\hline $0.45 \mathrm{~m}$ & 49.9 & 1.1 & 58.6 & 1.8 & 7.3 \\
\hline \multicolumn{6}{|l|}{ Growing seasons } \\
\hline 2010-2011 & 45.4 & $0.9^{* *}$ & $47.9 * *$ & $1.1 * *$ & $4.8^{* *}$ \\
\hline 2011-2012 & 47.9 & 1.1 & 58.6 & 1.8 & 7.9 \\
\hline Mean & 46.7 & 1.0 & 53.3 & 1.4 & 6.4 \\
\hline
\end{tabular}

*and**Significant by the LSD test, at 5 and $1 \%$ probability, respectively. $\mathrm{SG}$, signal grass. 
Table 5. Interaction between cutting heights, crop systems - corn monocropped with residual regrowth of signal grass (Urochloa decumbens) and corn intercropped with palisade grass (Urochloa brizantha) -, and growing seasons for light interception (LI), leaf area index (LAI), and forage dry matter yield of pasture (FDMYP) ${ }^{(1)}$.

\begin{tabular}{|c|c|c|c|c|}
\hline \multirow[t]{2}{*}{ Pasture } & \multicolumn{2}{|c|}{ Cutting heights } & \multicolumn{2}{|c|}{ Growing seasons } \\
\hline & $0.20 \mathrm{~m}$ & $0.45 \mathrm{~m}$ & First & Second \\
\hline & \multicolumn{4}{|c|}{ LI (\%) after harvest for silage } \\
\hline Signal grass regrowth & $26.7 \mathrm{bA}$ & $29.4 \mathrm{bA}$ & $29.4 \mathrm{bA}$ & $26.7 \mathrm{bA}$ \\
\hline \multirow[t]{2}{*}{ Palisade grass } & $60.2 \mathrm{aB}$ & $70.5 \mathrm{aA}$ & $61.5 \mathrm{aB}$ & $69.2 \mathrm{aA}$ \\
\hline & \multicolumn{4}{|c|}{ LAI after harvest for silage } \\
\hline Signal grass regrowth & $0.6 \mathrm{bA}$ & $0.6 \mathrm{bA}$ & $0.5 \mathrm{bA}$ & $0.6 \mathrm{bA}$ \\
\hline \multirow[t]{2}{*}{ Palisade grass } & $1.3 \mathrm{aB}$ & $1.6 \mathrm{aA}$ & $1.3 \mathrm{aB}$ & $1.6 \mathrm{aA}$ \\
\hline & \multicolumn{4}{|c|}{ LI $(\%)$ at the pre-grazing period } \\
\hline Signal grass regrowth & $26.7 \mathrm{bA}$ & $32.8 \mathrm{bA}$ & $26.7 \mathrm{bA}$ & $32.8 \mathrm{bA}$ \\
\hline \multirow[t]{2}{*}{ Palisade grass } & $69.2 \mathrm{aB}$ & $84.5 \mathrm{aA}$ & $69.2 \mathrm{aB}$ & $84.5 \mathrm{aA}$ \\
\hline & \multicolumn{4}{|c|}{ LAI at the pre-grazing period } \\
\hline Signal grass regrowth & $0.7 \mathrm{bA}$ & $0.7 \mathrm{bA}$ & $0.7 \mathrm{bA}$ & $0.7 \mathrm{bA}$ \\
\hline \multirow[t]{2}{*}{ Palisade grass } & $1.6 \mathrm{aB}$ & $2.8 \mathrm{aA}$ & $1.6 \mathrm{aB}$ & $2.8 \mathrm{aA}$ \\
\hline & \multicolumn{4}{|c|}{ Dry matter yield of pastures (FDMYP, $\mathrm{Mg} \mathrm{ha}^{-1}$ ) } \\
\hline Signal grass regrowth & $4.8 \mathrm{bA}$ & $5.5 \mathrm{bA}$ & - & - \\
\hline Palisade grass & $6.1 \mathrm{aB}$ & $9.0 \mathrm{aA}$ & - & - \\
\hline
\end{tabular}

(1) Means followed by equal letters, lowercase in the columns and uppercase in the lines, do not differ by the LSD test, at 5\% probability.

were better in the second growing season, which provided greater forage dry matter yield of pasture (Table 4). The LI and LAI results explain the better recovery of palisade grass intercropped with corn at the cutting height of $0.45 \mathrm{~m}$ for silage, increasing FDMYP after harvest for silage and pre-grazing by lambs in the winter/spring season (Table 5). Thus, it can result in a decreased removal of palisade grass tillers, compromising not the pasture formation. In the intercrop system, the grass is sown at a time when there is water availability and suitable temperature and when after the corn harvest there is still some rain, allowing the pasture formation, as verified in this study (Table 1).

\section{Conclusion}

Corn (Zea mays) intercropped with palisade grass (Urochloa brizantha) improves silage and pasture yield, besides providing a greater land use efficiency, compared with the monocrop or pasture, mainly at the $0.45-\mathrm{m}$ cutting height.

\section{Acknowledgments}

To Fundação de Amparo à Pesquisa do Estado de São Paulo (Fapesp), for grants (Nos. 2011/12155-3 and 2010/12992-0); to Fundação para o Desenvolvimento da Unesp (Fundunesp), for financial support (grant No. 0538/011/14-PROPe/CDC); to Coordenação de Aperfeiçoamento de Pessoal de Nível Superior (Capes), for grant to the first author; and to Conselho Nacional de Desenvolvimento Científico (CNPq), for an award for excellence in research granted to the second, third, and sixth authors.

\section{References}

AGEGNEHU, G.; GHIZAW, A.; SINEBO, W. Yield performance and land-use efficiency of barley and faba bean mixed cropping in Ethiopian highlands. European Journal of Agronomy, v.25, p.202-207, 2006. DOI: 10.1016/j.eja.2006.05.002.

ARAUJO, L.C. de; SANTOS, P.M.; MENDONÇA, F.C.; LIMA, N.R.C. de B. Development of maize and palisadegrass plants cultivated in intercrop under water deficit. Revista Brasileira de Zootecnia, v.40, p.1397-1404, 2011. DOI: 10.1590/S151635982011000700001 .

BERGAMASCHI, H.; DALMAGO, G.A.; BERGONCI, J.I.; BIANCHI, C.A.M.; MÜLLER, A.G.; COMIRAN, F.; HECKLER, B.M.M. Distribuição hídrica no período crítico do milho e produção de grãos. Pesquisa Agropecuária Brasileira, v.39, p.831-839, 2004. DOI: 10.1590/S0100-204X2004000900001.

BERNARDINO, F.S.; GARCIA, R. Sistemas silvipastoris. Pesquisa Florestal Brasileira, v.60, p.77-87, 2009. Edição especial. DOI: 10.4336/2009.pfb.60.77.

BIABANI, A.; HASHEMI, M.; HERBERT, S.J. Agronomic performance of two intercropped soybean cultivars. International Journal of Plant Production, v.2, p.215-222, 2008.

BORGHI, E.; CRUSCIOL, C.A.C.; TRIVELIN, P.C.O.; NASCENTE, A.S.; COSTA, C.; MATEUS, G.P. Nitrogen fertilization $\left({ }^{15} \mathrm{NH}_{4} \mathrm{NO}_{3}\right)$ of palisadegrass and residual effect on subsequent no-tillage corn. Revista Brasileira de Ciência do Solo, v.38, p.1457-1468, 2014. DOI: 10.1590/S010006832014000500011 .

CANTARELLA, H.; RAIJ, B. van; CAMARGO, C.E.O. Cereais. In: RAIJ, B. van; CANTARELLA, H.; QUAGGIO, J.A.; FURLANI, A.M.C. (Ed.). Recomendações de adubação e calagem para o Estado de São Paulo. 2.ed. rev. e atual. Campinas: Instituto Agronômico, 1997. p.43-71. (IAC. Boletim técnico 100).

CARVALHO, P.C. de F.; ANGHINONI, I.; MORAES, A. de; SOUZA, E.D. de; SULC, R.M.; LANG, C.R.; FLORES, J.P.C.; LOPES, M.L.T.; SILVA, J.L.S. da; CONTE, O.; WESP, C. de L.; LEVIEN, R.; FONTANELI, R.S.; BAYER, C. Managing grazing animals to achieve nutrient cycling and soil improvement in no- 
till integrated systems. Nutrient Cycling in Agroecosystems, v.88, p.259-273, 2010. DOI: 10.1007/s10705-010-9360-x.

CEPAGRI. Centro de Pesquisas Meteorológicas e Climáticas Aplicadas a Agricultura. Clima dos Municípios Paulistas: Botucatu. 2013. Available at: $<$ http://www.cpa.unicamp.br/outrasinformacoes/clima_muni_086.html\#>. Accessed on: Feb. 182014.

COSTA, K.A. de P.; ROSA, B.; OLIVEIRA, I.P. de; CUSTÓDIO, D.P.; SILVA, D.C. e. Efeito da estacionalidade na produção de matéria seca e composição bromatológica da Brachiaria brizantha cv. Marandu. Ciência Animal Brasileira, v.6, p.187-193, 2005.

COSTA, N.R.; ANDREOTTI, M.; GAMEIRO, R. de A.; PARIZ, C.M.; BUZETTI, S.; LOPES, K.S.M. Adubação nitrogenada no consórcio de milho com duas espécies de braquiária em sistema plantio direto. Pesquisa Agropecuária Brasileira, v.47, p.10381047, 2012. DOI: 10.1590/S0100-204X2012000800003.

CRUSCIOL, C.A.C.; MATEUS, G.P.; NASCENTE, A.S.; MARTINS, P.O.; BORGHI, E.; PARIZ, C.M. An innovative crop-forage intercrop system: early cycle soybean cultivars and palisadegrass. Agronomy Journal, v.104, p.1085-1095, 2012. DOI: 10.2134/agronj2012.0002.

CRUSCIOL, C.A.C.; MATEUS, G.P.; PARIZ, C. M.; BORGHI, E.; COSTA, C.; SILVEIRA, J.P.F. da. Nutrição e produtividade de híbridos de sorgo granífero de ciclos contrastantes consorciados com capim-marandu. Pesquisa Agropecuária Brasileira, v.46, p.1234-1240, 2011. DOI: 10.1590/S0100-204X2011001000017.

CRUSCIOL, C.A.C.; NASCENTE, A.S.; MATEUS, G.P.; BORGHI, E.; LELES, E.P.; SANTOS, N.C.B. Effect of intercropping on yields of corn with different relative maturities and palisadegrass. Agronomy Journal, v.105, p.599-606, 2013. DOI: 10.2134/agronj2012.0426.

CRUSCIOL, C.A.C.; NASCENTE, A.S.; MATEUS, G.P.; PARIZ, C.M.; MARTINS, P.O.; BORGHI, E. Intercropping soybean and palisade grass for enhanced land use efficiency and revenue in a no till system. European Journal of Agronomy, v.58, p.53-62, 2014. DOI: 10.1016/j.eja.2014.05.001.

KLUTHCOUSKI, J.; AIDAR, H. Uso da integração lavourapecuária na recuperação de pastagens degradadas. In: KLUTHCOUSKI, J.; STONE, L.F.; AIDAR, H. (Ed.). Integração lavoura-pecuária. Santo Antônio de Goiás: Embrapa Arroz e Feijão, 2003. p.185-223.

MATEUS, G.P.; CRUSCIOL, C.A.C.; BORGHI, E.; PARIZ, C.M.; COSTA, C.; SILVEIRA, J.P.F. da. Adubação nitrogenada de sorgo granífero consorciado com capim em sistema de plantio direto. Pesquisa Agropecuária Brasileira, v.46, p.1161-1169, 2011. DOI: 10.1590/S0100-204X2011001000007.

MATEUS, G.P.; CRUSCIOL, C.A.C.; BORGHI, E. Integrated crop-livestock: the new green revolution in the tropics. Pesquisa e Tecnologia, v.4, p.1-5, 2007.

MATEUS, G.P.; CRUSCIOL, C.A.C.; PARIZ, C.M.; BORGHI, E.; COSTA, C.; MARTELLO, J.M.; FRANZLUEBBERS, A.J.;
CASTILHOS, A.M. Sidedress nitrogen application rates to sorghum intercropped with tropical perennial grasses. Agronomy Journal, v.108, p.433-447, 2016. DOI: 10.2134/agronj2015.0236.

MEAD, R.; WILLEY, R.W. The concept of a 'land equivalent ratio' and advantages in yields from intercropping. Experimental Agriculture, v.16, p.217-228, 1980. DOI: 10.1017/ S0014479700010978.

PARIZ, C.M.; ANDREOTTI, M.; BERGAMASCHINE, A.F.; BUZETTI, S.; COSTA, N.R.; CAVALLINI, M.C.; ULIAN, N. de A.; LUIGGI, F.G. Yield, chemical composition and chlorophyll relative content of Tanzania and Mombaça grasses irrigated and fertilized with nitrogen after corn intercropping. Revista Brasileira de Zootecnia, v.40, p.728-738, 2011a. DOI: 10.1590/ S1516-35982011000400005.

PARIZ, C.M.; ANDREOTTI, M.; BUZETTI, S.; BERGAMASCHINE, A.F.; ULIAN, N. de A.; FURLAN, L.C.; MEIRELLES, P.R. de L.; CAVASANO, F.A. Straw decomposition of nitrogen-fertilized grasses intercropped with irrigated maize in an integrated crop-livestock system. Revista Brasileira de Ciência do Solo, v.35, p.2029-2037, 2011b. DOI: 10.1590/S010006832011000600019.

PORTES, T. de A.; CARVALHO, S.I.C. de; OLIVEIRA, I.P. de; KLUTHCOUSKI, J. Análise do crescimento de uma cultivar de braquiária em cultivo solteiro e consorciado com cereais. Pesquisa Agropecuária Brasileira, v.35, p.1349-1358, 2000. DOI: 10.1590/ S0100-204X2000000700009.

RAIJ, B. van; ANDRADE, J.C. de; CANTARELLA, H.; QUAGGIO, J.A. (Ed.). Análise química para avaliação da fertilidade de solos tropicais. Campinas: IAC, 2001. 284p.

REZENDE, A.V. de; WATANABE, D.J.; RABÊLO, F.H.S.; RABELO, C.H.S.; NOGUEIRA, D.A. Características agronômicas, bromatológicas e econômicas de alturas de corte para ensilagem da cultura do milho. Semina: Ciências Agrárias, v.36, p.961-970, 2015. DOI: 10.5433/1679-0359.2015v36n2p961.

SANTOS, H.G. dos; JACOMINE, P.K.T.; ANJOS, L.H.C. dos; OLIVEIRA, V.A. de; OLIVEIRA, J.B. de; COELHO, M.R.; LUMBRERAS, J.F.; CUNHA, T.J.F. (Ed.). Sistema brasileiro de classificação de solos. 2.ed. Rio de Janeiro: Embrapa Solos, 2006. 306p.

SHAPIRO, S.S.; WILK, M.B. An analysis of variance test for normality (complete samples). Biometrika, v.52, p.591-611, 1965. DOI: $10.1093 /$ biomet/52.3-4.591.

TAKIM, F.O. Advantages of maize-cowpea intercropping over sole cropping through competition indices. Journal of Agriculture and Biodiversity Research, v.1, p.53-59, 2012.

WU, Z.; ROTH, G. Considerations in managing cutting height of corn silage. College Park: Pennsylvania State University, 2005. p.3-72. (Extension publication DAS 03-72).

$\overline{\text { Received on August 20, } 2016 \text { and accepted on October 31, } 2016}$ 